\title{
Contemporary challenges in social work
}

\author{
Agnieszka Katarzyna Gębora \\ Higher School of Wholesome Education and Social Sciences, \\ 21 Kamińskiego St., 90-229 Łódź, Poland \\ E-mail address: k.gebora@wp.pl
}

\begin{abstract}
The welfare is an area of social policy which is aimed at supporting persons and families aiming at satisfying the needs, as well as enabling persons and families living in conditions suiting the human dignity, preventing difficult life situations of humans. The development of modern societies and the progressing democratization of social relations cause the civilization hazards which make existing social issues deep. The social work face with the challenge of developing new strategies of bringing help in incessantly changing reality.
\end{abstract}

Keywords: social work; problems; threats; challenge; ruling out

\section{INTRODUCTION}

The name of the social work involves the intentional and organised help of modern societies for the society members who are economically, socially or physically inefficient.

In democracies the social work is included in the basic means of the welfare. Comprehending the social work is defined very differently depending on purposes which, they assign to an action which it describes.

A little bit differently the social work is being defined by the Polish teacher and the educationalist Radlińska Helena, she describes it with name of getting and accumulating human powers, consists in streamlining them and the organization of the joint action for the good of people (Radlińska, H. 1928)

The Committee of the European Council determines the comprehensive and broad definition of the social work:

The social work is a peculiar occupational activity, being aimed at a better mutual adaptation of persons, families, groups and the social environment which, they live in and developing feeling the personal dignity and individuals responsibilities for means of appealing to potential options of individual persons, to interproffesional connections, as well as of powers and public means. (Szatur-Jaworska B., 1995)

Whereas the International Association of Schools of the Social Work developed the general international definition, determining, that: 


\begin{abstract}
The social work supports public changes, problem solving in the human relationships and getting powers and the freedom out of people so that they can achieve the prosperity. Using the theory of human behaviours and social systems the social work has an influence where people enter interactions with the environment. Principles of human rights and the social justice are the foundation of the social work. (Wolska-Prylińska D., 2010)
\end{abstract}

In every contemporary state, in which the social work is being conducted, it is located in a wide range of the immediate, individualized welfare, determined as public services. Public services include care services, i.e. the help in the housekeeping, hygienic procedures and nursing and financial help (financial or material).

This notional category has Polish origins in widely understood community work. The meaning of this work involves transforming the living conditions and the development with aroused and streamlined human powers. During the action the conditions, in which the need of social intervention occurs are being identified. It is possible to consider issues of the social work from a point of view as the 'donor' and it is traditionally assessed as positive, irrespective of the scope of assistance, the situation and the consequence of shown benefits. It can also be analysed from a point of view of the recipient at stressing such features as: adequacy, effectiveness, atmosphere of the shown help.

In Poland not only a help to economically failing people is located in its field, but also diverse therapeutic activity, revalidational and educational referred to individuals and families which they have difficulty in public functioning because of one's social situation or of physical, psychological, interpersonal gaps or of all kinds of addictions.

The basic definition of the social work being in force at present was put down on Polish land in the Act of the welfare from 12 ${ }^{\text {th }}$ March 2004 (Journal of Laws from 2004 No. 64 position 593 article 45 as amended, point 1). According to it the social work is being provided for the improvement in functioning of persons and families in their social environment. The social work is being conducted:

1. with persons and families in order to develop or to improve their activity and the practical self-reliance;

2. with the local community in order to provide both the coordination and activities of the institution and organizations significant for catering the community members needs $[\ldots]$ '.

This presentation in principle does not diverge in terms of content from the definition accepted by the general assembly of International Federation of Social Workers (IFSW) in July 2000 .

Analysing axiological aspects of the social work, the role of taking back to the value and their appropriate hierarchy should be emphasized, resulting from the primacy of man. The social work as the work which serves the man demands constant adapting oneself to the social reality. Here an issue of the change is substantial. At present we live in the world, in which the pace of living is very fast. Many changes take place clearly. In many cases adapting the activity is necessary to current situations, problems turning up in the given area of activity. In everyday life still new or old transformed social issues occur and in this way they generate tasks for the welfare. Transformations in the society, on a macro and micro social scale along with their complexity and the extensiveness, new system approaches and creative reflection over the need and issues extort active versus for the passive and ineffective social policy. 
The welfare is an area of social policy which is aimed at supporting persons and families aiming at satisfying the needs, as well as enabling persons and families living in conditions suiting the human dignity, preventing difficult life situations of persons and their families and taking appropriate actions to becoming independent and integrating with the social environment (Domżał U. A., 2011).

Also a profession of a social worker is evolving nowadays. From activity closed as part of the state institution, get for giving financial benefits away, bureaucratic and paternalistic it is heading towards the profession not assigned to only government administration authorities and self-government. Determined standards, models of action, moral values, norms of behaviours are supposed to characterize this profession. In quickly changing world one should make an attempt of challenges identifications which the changing Polish people are carrying, but with its domestic and European social policy, sense of direction personal entailing axiology, in the centre which the human welfare is standing for. The social work is activity, with profession in frames of the still developing field of study.

The profession of a social worker is included to one of most difficult, because it requires not only the vast knowledge but also enthusiasm, amazing sensitivity, tact to needs of others, appropriate attitude of the moral and huge propriety. Originally in organizations of the welfare men of goodwill, selflessly being active in associations and institutions of charity, welfare, folk education, disseminating culture were employees. Those are so-called community workers. Their activity constituted the tangle of trademarks evoking today feeling mixed up of embarrassment and the admiration.

The embarrassment that it is possible to be on duty for the second man without or for the little remuneration. However the admiration is inspiring the enthusiasm of the work for ideals, their zeal, the moral bravery and the kindliness to the ones, for who they wanted to be useful. Today's reality highlight the need of the community work regularity performed by the full-time staff, flexible in appropriate hours and as far as possible appropriately prepared for their tasks.

Workers of different kind of institutions who bring help to aid expecting persons' must in particular know well and help diligently and with the great commitment obey own professional ethics and present impeccable moral attitudes.

Therefore the following attributes should characterize a social worker: joie de vivre, awareness that all people as well as he or she herself or himself, constantly must deal problems with, the lack of the conformism, acknowledging that the majority of solutions in the life has a temporary nature, the self-awareness, the authenticity, the self-regard, the self-confidence, desire for increasing the freedom of choice at people and the control over the own life, the courage to tell customers about realistic aspects of their problems, the courage to take a risk of the failure in the achievement of the goals of the social work, the sensitivity to emotions, doubts, fears and emotional emotions of customer.

Carrying the social work out, a social worker must perform a lot of different roles and try to link them in practice. To the most important roles one should perform we can rank: the diagnostician, the adviser, the teacher, the animator, the intermediary, the coordinator, the modifier, the reformer, the lifeguard, the planner and the mediator (A. Wiśniewska-Mucha, 2005).

In relation to changing quickly reality in the vocational education of a social worker one should direct attention to the appropriate ratio between the basic, general and specialist knowledge and developing competent mass media of this knowledge. In training programmes for social workers more and more great diversity of sources are used which are aimed to stimulate imagination and sensitivities. Knowledge acquisition should be a process engaging the entire personality. 
In the career intervention should be a transfer of the acquired knowledge, so action must come from the thinking which a social worker verifies or known notions moderates, theories and standards or procedures of behaviours. In the vocational education theory and practice should be combined. The preparation must be held at universities, where the respect for the knowledge exists and care of its development. The theoretical preparation should merge how the most closely with the adequate respect for the practical, without which no vocational training course can to be effective.

The most important aspect however should be paid attention the fact that it is a very difficult work. Charity actions made in the everyday life, in the family circle, between friends pretend, that every person with the healthy mind and the good heart is competent to the performance of work social. However this way he is not. The being of the humanitarianism of this activity is a task for an exclusively chosen group of people.

Professionally the person works as a social worker can only that one who apart from the formal preparation is involved in the realization of the mission and the vision of the contemporary welfare, who understands the own professional role and identifies himself with helping propagating the aid for the mutual aid society, that is an animator of the local community. He or she must possess a skill of the independent work, but also the teamwork with all sorts of groups of people using from the welfare and with various specialists. He or she is communicative and enterprising. He or she is a manager of the welfare, being able to examine, to advertise, to sell, to monitor and to evaluate the entire range of social services. A social worker often provides these services directly to persons in need, using the huge autonomy and at the same time has a huge advantage over the recipient. It makes him the jointly responsible person for the fate of everyone who will use his offer.

A man is an object of influences of the social work, in addition it is the man who requires the help, because with own powers and possibilities will not overcome his difficult situations in life, in which he is. And so his fate depends, if not completely, it to say the least to a large extent from the ones who for this helping stayed appointed. From this way arising configuration (from one side the ones who help - on the other the ones who are helped) occurs directly a rank and meaning of moral aspects of the conduct of the ones who professionally help the others. A respect for the human dignity and defenses of this dignity, human rights for the selfdetermination, care of the equality of opportunity are a main idea of the social work.

The contemporary environment of the life is extremely diversified. From one side dynamic, supporting, giving the prospect of the development, whereas on the other more and more new and bigger barriers are formed which constitute the practical barrier for the more and more weak society. The decreasing fertility and the rising life span cause the ageing of the Polish people. Conclusions of the forecast indicate the considerable progress of this process. This demographic occurrence is resulting itself in a lot of problems.

The growth of the absolute number of seniors is connected with increasing burdening of the protection health system with care costs connected with this group of the population and brings the need of drawing strategic programmes up for older people in the support for real recognizing their health and socioeconomic situation. A need of the extension of all socialhealth services intended for this age group exists, of stimulating the social awareness what could create the chance for the man for overcoming inconveniences resulting from the ageing process (Domżał from., 2011). A rise in the demand for the social work will also take place.

The change is accompanying the man from the dawning of the mankind. The changing life environment brings new research, cognitive new challenges and as a result it requires the change in adapting of bringing help which is supposed to satisfy new needs. We live in the consumer society (Bardrillaud J., 2006), in the society of the late modernity (Giddens A., 2001), 
or in the society of the network (Castels. M., 2007). The Modernity erases or obscures the tradition. Roles the men perform in their lives are changing. The disintegration of current schemes, models or frames of reference implements the confusion which in a simple way leads individuals to conflict and problems in finding the own society role.

The consumerism never had such a total character and did not permeate almost all areas of the human life. The large impact for becoming known of such a phenomenon has the network-ness of our everyday lives and the broad influence of media for life and its perception. The meditative perception of the real world causes such phenomenon, that the man can see and can hear what is simple and pleasant- attractive. Simultaneous information overload and stimuli causes that especially the younger generation is not able to assess reality objectively. The confusion of young people and the lack of social bonds or impoverishing them, cause that the individual loses the ability of rational action. He is not able also to determine what one should be guided when choosing the practical way by (Bogunia-Borowska, 2008).

The present reality endow us with globalization, individuation, gender revolution (changes in the interpretation range of the sex identity), the global risk, the underemployment of the classification and the working potential. The unpredictability of events creates the context, in which the possibility of exercising control, acquiring the confidence and the safety is falling.

The development of modern societies and the progressing democratization of social relations cause the civilization hazards which make existing problems deeper. One of the most important issues being in the range of sociologists and social teachers interests is a marginalisation and a social exclusion of individuals and entire groups. Marginalisation, unemployment the poverty in Poland means the lack of the participation in the social life.

This phenomenon is visible very well both in the country as well as urban environment. Social groups (unemployed, homeless) and groups excluded from the community because of the specific dissimilarity, linguistic, religious or ethnic strangeness are exposed to manifestations of the discrimination and the segregation.

The largeness of young people finishing university studies stays jobless. In fear of the inactivity they decide to pick next studies up what in consequence leads to barriers in the passage from the school system to the occupational activity. A problem of the emotional poverty appears. The poverty is a state of gaps of different kinds and what's more of such a kind of gaps and about such sizes the specific man does not meet his essential needs, feels humiliated in one's human dignity, goes through a crisis, of which with own powers cannot overcome. In the lives of poor people elements not-supporting integration and building the family up appear (lack of the work or fear of its loss, helplessness, marking, ruling out). Feeling the deprivation and worsening the medical condition accompany it.

Very often young Poles emigrate 'to earn one's bread and butter'. It unfortunately worsens the situation. The man experiences the phenomena of the 'split' My body is abroad and my thoughts are at home, in the country. Persons who were successful, live abroad, educate their children there still after the certain time start losing their own identity. The ones who were not successful in one country are seeking the new place to settle down. It is a phenomenon 'of rummaging about without sense border'. Relations and family bonds about more than_territorial character cause alienation and growing frustration. The individual loses the feeling of membership. For her the house isn't still there but no longer here. A problem of the migration homelessness appears. The torn, unfulfilled man falls down into more and more wide spheres of isolating. The lack of the social and psychological sense of security impells the man to the return to the country. Collision with other reality a tendency to self-separating 
induces. The solitude of the man paradoxically amongst other people is becoming a source of disasters, anxieties and sorrows.

On one hand an ageing society, on the other lost young people cause, that a demand for the specialist public assistance is growing. A new strategy which regards supporting a separate identity at the identification, reflective constructing the biography of the individual and raising the awareness of own laws (Universal Declaration of Human Rights) is the reason for the latest model of the social work.

\section{CONCLUSIONS}

To sum up about contemporary challenges at the social work one should return deliberations special attention that existing social issues require professional actions letting eliminate mentioned phenomena so that not to pose a threat to the contemporary man. It is a challenge for the determined social policy of the state, self-government institutions, associations and social organizations, the foundation and grassroots movements and sensitive individuals for harm of other man.

Overcoming social issues, experience exceptionally difficult (because of the specificity) poses a challenge not only for the individual, but for most for all professional interveners, both in the local as well as global scale. In the process a creative posture of a social worker is important, involving him in the solving social problem (threats), the professionalism of provided services and determining the space of functioning. It has this key importance in the socioeconomic current situation of the country, particularly that still the amount of areas of the social exclusion and social issues increase.

\section{References}

[1] Bardrillaud J., Społeczeństwo konsumpcyjne. Jego mity i struktury, Wydawnictwo Sic!, Warszawa 2006.

[2] Bogunia-Borowska M., Codzienność życie społecznego-wyzwania dla socjologii XXI wieku, [w:] Bogunia-Borowska M., Socjologia codzienności, Wydawnictwo Znak, Kraków 2008.

[3] Castels M., Społeczeństwo sieci, PWN, Warszawa 2007.

[4] Danilewicz W. (red), Oblicza współczesności w perspektywie pedagogiki społecznej, Wydawnictwo Akademickie Żak, Warszawa 2009.

[5] Domżał U. A., Pomoc społeczna - jej funkcje w resocjalizacji, Brno, 2011.

[6] Domżał Z., Pomoc społeczna państwa i formy jej udzielania, [w:] Socialni pedagogika v souvislostech globalni krize, Zbornik Prispevku z mezinarodni konference, (red. Bargel M.), Brno, 2011.

[7] Giddens A., Nowoczesność i tożsamość. „Ja” $i$ społeczeństwo $w$ epoce późnej nowoczesności, PWN, Warszawa 2001.

[8] Piekarski J., Pilch T., Theiss W., Urbaniak-Zając D., (red), Edukacja społeczna wobec problemów współczesnego człowieka i społeczeństwa, Wyd. Uniwersytetu Łódzkiego, Łódź 2010. 
[9] Radlińska H., Szkoła pracy społecznej w Polsce, 1928 [za:] Szatur-Jaworska B., Teoretyczne podstawy pracy socjalnej [w:] T. Pilch, I. Lepalczyk (red.), Pedagogika Społeczna, Kraków 1995.

[10] Radziewicz-Winnicki A. (red), Pedagogika wobec współczesności, Wydawnictwa Akademickie i profesjonalne, Warszawa 2008.

[11] Szatur-Jaworska B., Teoretyczne podstawy pracy socjalnej [w:] Pedagogika Społeczna, pod. red: T. Pilch, I. Lepalczyk, Kraków 1995.

[12] Wiśniewska-Mucha A., O przyszłości pracy socjalnej w Polsce, „Pracownik socjalny” 2005, nr 8.

[13] Wolska-Prylińska D., Projekt socjalny w kształceniu i działaniu społecznym, wyd. Śląsk, Katowice 2010. 